\title{
Isolated Scaphoid Dislocation: A Case-Report
}

Luxação Isolada do Escafóide: Relato de Caso

Luxación Aislada de Escafoides: Reporte de un Caso

Sara Dadona Correia SERRANO Hand Surgeon and Microsurgeon of Hand Division of Hospital Santa Casa de Misericórdia de Ribeirão Preto, Ribeirão Preto, SP, Brazil Luis Guilherme Rosifini Alves REZENDE Hand Surgeon and Microsurgeon of Hand Division of Ribeirao Preto Medical School of University of São Paulo, Ribeirão Preto, SP, Brazil https://orcid.org/0000-0002-2037-0135

\begin{abstract}
Isolated dislocations of the scaphoid are rare conditions in orthopedic practice and can be underdiagnosed. Early diagnosis and treatment are established by the current literature. Despite the few case reports described in the literature, treatment standards are still not well established, with different management techniques for this condition. We present the case report of a 31 -yearold patient, presenting isolated dislocation of the left scaphoid. He underwent surgical management with closed reduction and percutaneous fixation with Kirschner wires. After removing the wires, the patient underwent physical therapy. His functional outcomes showed good recovery of function and range of motion of the wrist.
\end{abstract}

Descriptors: Scaphoid Bone; Dislocations; Hand Injuries.

Resumo

As luxações isoladas do escafoide são condições raras na prática ortopédica e podem ser subdiagnosticadas. O diagnóstico precoce e o tratamento são estabelecidos pela literatura atual. Apesar dos poucos relatos de casos descritos na literatura, os padrões de tratamento ainda não estão bem estabelecidos, com diferentes técnicas de manejo para essa condição. Apresentamos o relato de caso de um paciente de 31 anos, apresentando luxação isolada do escafoide esquerdo. Foi submetido a tratamento cirúrgico com redução fechada e fixação percutânea com fios de Kirschner. Após a retirada dos fios, a paciente foi submetida à fisioterapia. Seus resultados funcionais mostraram boa recuperação da função e amplitude de movimento do punho.

Descritores: Ortodontia; Resinas Compostas; Fotoiniciadores Dentários; Luzes de Polimerização Odontológica.

\section{Resumen}

Las luxaciones aisladas del escafoides son condiciones raras en la práctica ortopédica y pueden estar infradiagnosticadas. El diagnóstico y tratamiento precoces están establecidos por la literatura actual. A pesar de los pocos reportes de casos descritos en la literatura, los estándares de tratamiento aún no están bien establecidos, con diferentes técnicas de manejo para esta condición. Presentamos el caso clínico de un paciente de 31 años, que presenta luxación aislada de escafoides izquierdo. Se realizó manejo quirúrgico con reducción cerrada y fijación percutánea con agujas de Kirschner. Después de retirar los cables, el paciente se sometió a fisioterapia. Sus resultados funcionales mostraron una buena recuperación de la función y el rango de movimiento de la muñeca.

Descriptores: Hueso Escafoides; Luxaciones; Traumatismos de la Mano.

INTRODUCTION

Isolated scaphoid dislocations are rare conditions when compared to perilunate dislocation and carpal injuries. Few cases are described in the literature. It was first reported by Higgs in 1930 and since then, few case reports have been published ${ }^{1}$. Its injury mechanism is believed to be the extension of the wrist associated with ulnar deviation. Under normal conditions, this trauma mechanism generates a fracture of the radial styloid or scaphoid fracture. The complexity of the injury is related to the associated ligament injuries.

In 1993, Richard et al., classified isolated scaphoid dislocations as simple or complex injuries $^{2}$. Later, in 1998, Leung et al. classified this type of injury as primary or secondary, simple or complex, total or partial, and as to its direction. Primary injuries are those whose dislocation is the result of direct trauma. Secondary lesions occur after the reduction of a carpal dislocation, and the scaphoid remains dislocated. Complex injuries present changes in the distal carpal row or the relationship between the fourth and fifth rays ${ }^{3}$. While simple dislocations involve only the radioscaphoid and scapholunate joints.

The total type is that which does not remain any ligament attachment. The partial type is the most common, in which there are still ligament attachments, with the ligaments of the STT joint commonly intact. Thus, the deviation in the proximal pole is observed. The direction of dislocation as volar or dorsal has also been reported. Volar and ulnar dislocations have a higher risk of acute compression of the median nerve. Leung et al. developed a classification for isolated scaphoid dislocation according mechanism of trauma into primary or secondary, simple or complex, partial or total, and direction of dislocation (Figure 1).

They are more common in young, active male individuals. Unfortunately, up to $50 \%$ of cases are late diagnosed, which can compromise the scaphoid viability, reaching poor outcomes to this pattern of injury.

Acute injuries can be managed by closed reduction and fixation with Kirschner wires or ligament repair. However, in late presentation injuries, there may be a need for resection of the scaphoid and procedures that influence carpal dynamics, such as carpectomy of the proximal row or four-corner arthrodesis, and even total arthrodesis of the wrist, if not diagnosed in time.

The aim of this study is to present the case report of an isolated scaphoid dislocation in an active male patient and its postoperative result. 


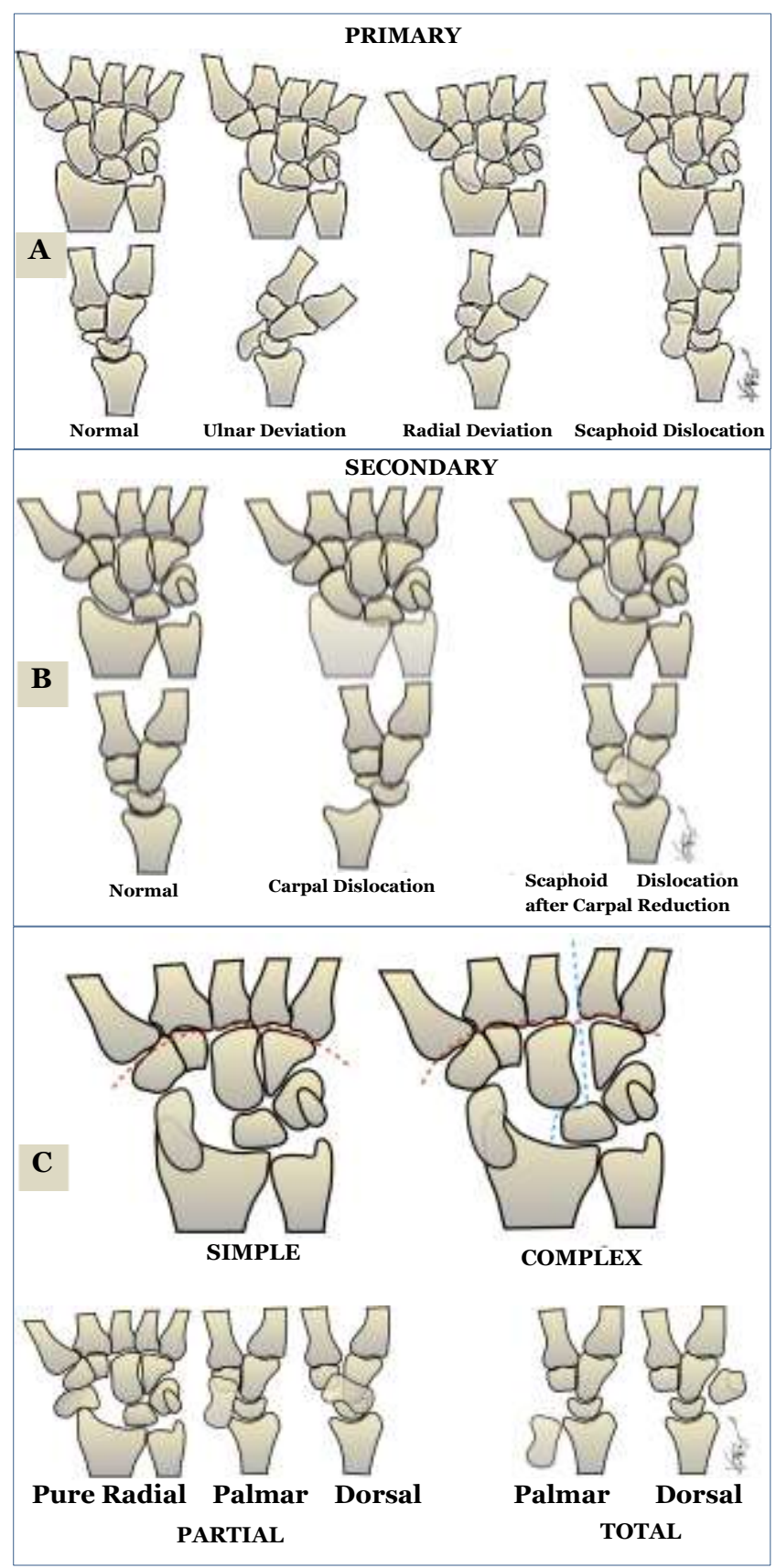

Figure 1. Leung et al. $^{3}$ classification for isolated scaphoid dislocation (Illustration made by Luis Guilherme Rosifini Alves Rezende). A. Primary. B. Secondary. C. Simple or Complex, Partial or Total, and Direction of Dislocation.

CLINICAL CASE

A 31-year-old male patient with trauma in dorsiflexion and supination of the wrist due a lathe machine, without comorbidities, presenting pain, swelling, loss of movement of his right wrist and symptoms of acute compression of the median nerve. He sought orthopedic care, and the radiograph presented isolated scaphoid dislocation, as seen in Figure 2.

We opted for emergency surgical management, with closed reduction and carpal fixation with Kirschner wires (Figure 2). The symptoms of compression of the median nerve were relieved immediately after de surgery.

The Kirschner wires were removed after 8 weeks and we began physiotherapy for a range of motion, which was maintained for another 6 weeks. The radiograph twenty-four months after the operation showed good positioning of the scaphoid, without any carpal instability (Figure 3) or avascular necrosis.

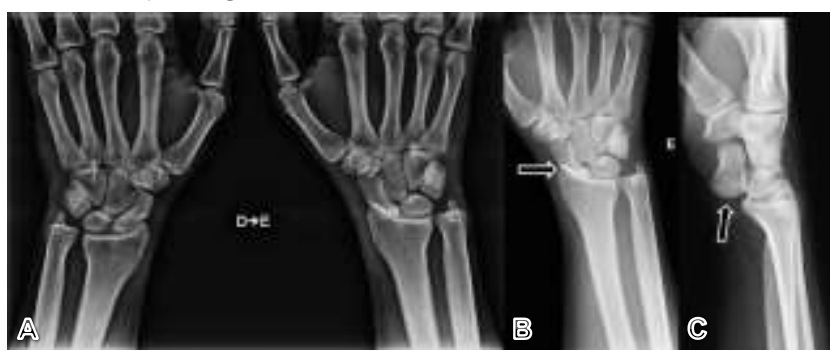

Figure 2. A. Radiograph with AP view compared to the right and left wrists. Slight overlap of the scaphoid in relation to the carpal bones. B. AP radiography of the left wrist with overlap of the scaphoid in relation to the radius and capitate (arrow). C. Isolated volar dislocation of the scaphoid (arrow), still in contact with the trapezius.

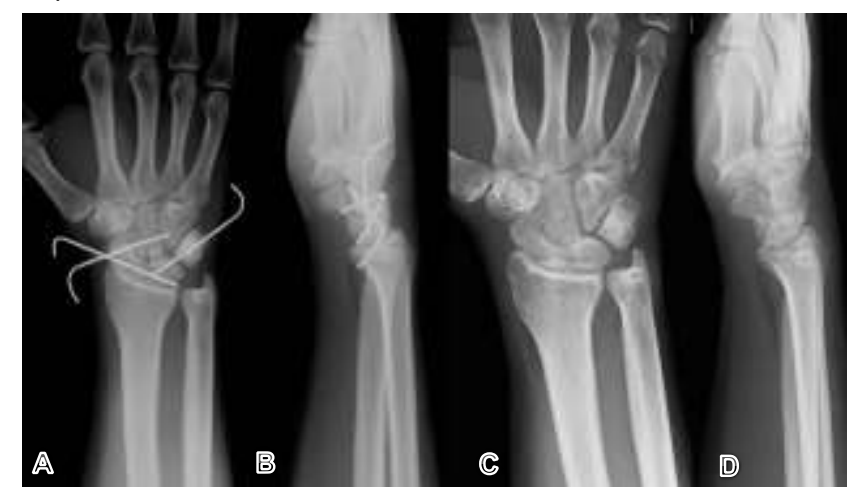

Figure 2. Radiography in $\mathrm{AP}(\mathbf{A})$ and Lateral (B) views with stabilization of the carpal bones with Kirschner wires. Radiography in AP (C) and Lateral (D) views of the carpal bones after 24 months postoperatively.

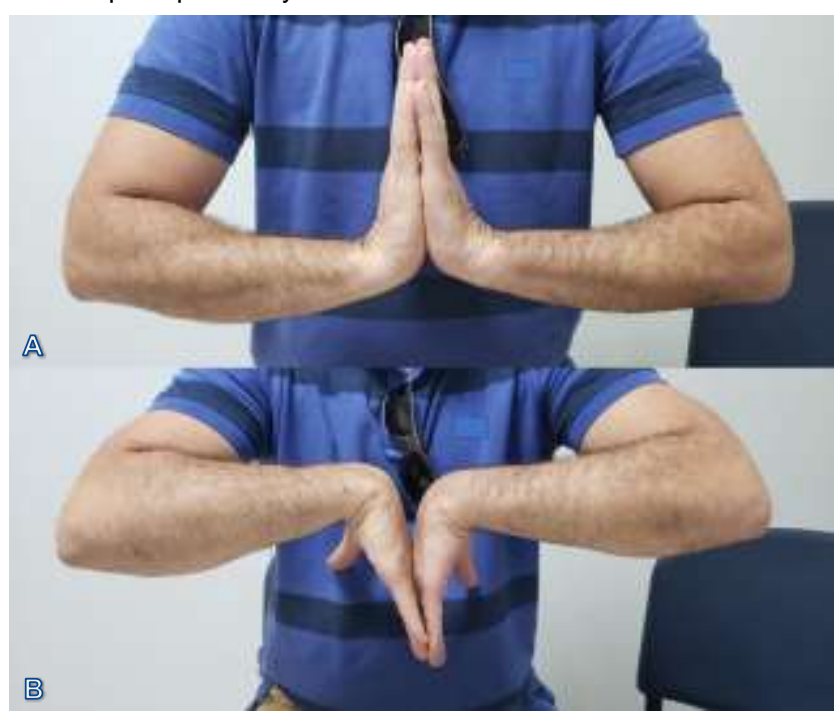

Figure 3. Wrist range of motion in extension (A) and flexion (B) after 24 months postoperatively.

The functional outcome at 24 months showed good flexion and extension of the wrist, as seen in Figure 4 . He reached $80^{\circ}$ of extension, $80^{\circ}$ of flexion, $30^{\circ}$ of ulnar deviation and $25^{\circ}$ radial and grip strength of $40 \mathrm{kgf}$. The patient has no complaints of pain or functional impairment and was able to return to his previous activities and work. 


\section{DISCUSSION}

Isolated scaphoid dislocations are rare events in the literature, with few cases described. Leung et al. ${ }^{3}$ believed that it could be one of the final stages of scapholunate injuries, and the severity would be related to the number of affected ligaments. The main prognostic factor reported was the delay in treatment, with a delay of more than 2 to 3 weeks achieving worse outcomes. Other factors that influence the outcome are age, poor reduction, and difficulty in recognizing the injury.

In agreement with what was advocated by Leung et al., we also found a good outcome in the early management. The delay between the moment of trauma, diagnosis and managment in the operating room was 8.4 hours. Our functional outcome also corroborated those reported by other authors. In this case, we opted for closed reduction and fixation with Kwires, which were maintained for 8 weeks. After removing the K-wires, we began a physical therapy protocol to achieve range of motion, reaching satisfactory outcomes.

In Brazil, Couto et al. ${ }^{4}$ reported an isolated scaphoid dislocation with a 17-month follow-up. Closed reduction and percutaneous fixation with $\mathrm{K}$-wires were performed and maintained for six weeks, obtaining the satisfactory functional outcome. Arthroscopy was used by Horton et al. $^{5}$ however, without images available to evaluate in their study.

The diagnosis can be made by radiography in AP and lateral views. It is important to emphasize the need for at least two radiographic views for the diagnosis. Figure $2 \mathrm{~A}$ shows the comparative AP radiography views of the right and left wrists, and, despite an overlap of the scaphoid on the carpal bones, it could be unnoticed. Additional imaging methods, such as CT and MRI, can also be used to assess associated injuries. Arthroscopy can also be used for the diagnosis and treatment of carpal ligament injuries. In our case, the diagnosis was made by simple radiography in AP and lateral views.

We believe that, despite the severity of the injury, surgical management with closed reduction and percutaneous fixation is a relatively effective method, and that it can bring about good postoperative functional outcomes, as seen in Figure 4.

Other alternatives such as ligament reconstruction with anchors can also be performed. There are reports of late diagnosis, and both ligament reconstruction or carpal procedures, such as carpectomy of the proximal row, were performed. ${ }^{6,7}$
It is important to remember that symptoms of compression of the median nerve could be present, especially in cases of volar dislocation ${ }^{8}$. Szabo et al. ${ }^{9}$ believe that the complexity of ligament injuries, assessed by radiography, can predict the need for open surgery.

Despite the different management methods, we believe that the early approach is more appropriate for isolated scaphoid dislocations. However, at this moment, there are no studies that define the best management for these conditions.

REFERENCES

1. Higgs SL. Two Cases of Dislocation of Carpal Scaphoid. Proc R Soc Med. 1930;23(9): 1337-39.

2. Richards RS, Bennett JD, Roth JH. Scaphoid dislocation with radial-axial carpal disruption. AJR Am J Roentgenol. 1993;160(5):1075-76.

3. Leung YF, Wai YL, Kam WL, Ip PS. Solitary dislocation of the scaphoid. From case report to literature review. J Hand Surg $\mathrm{Br}$. 1998;23(1):88-92.

4. Couto P, Chambriard C, Osório L, Sena N, Knackfuss I, Menegassi Z. Luxação Isolada do Escafóide Relato de Caso. Rev Bras Ortop. 1996;31(4):358-60.

5. Horton T, Shin AY, Cooney WP 3rd. Isolated scaphoid dislocation associated with axial carpal dissociation: an unusual injury report. J Hand Surg Am. 2004;29(6):1102-8.

6. Amaravati RS, Saji M, Rajagopal H, Gururaj. Neglected dorsal dislocation of the scaphoid. Indian J Orthop. 2009;43(2):213-215.

7. Baek JR, Cho SH, Lee YS, Roh YH. Neglected isolated scaphoid dislocation. Indian J Orthop. 2016;50(6):693-96.

8. Takami H, Takahashi S, Ando M. Dislocation of the carpal scaphoid associated with median nerve compression: case report. J Trauma. 1992;33(6):921-23.

9. Szabo RM, Newland CC, Johnson PG, Steinberg DR, Tortosa R. Spectrum of injury and treatment options for isolated dislocation of the scaphoid. A report of three cases. J Bone Joint Surg Am. 1995;77(4):608-15. 


\section{CONFLICTS OF INTERESTS}

The authors declare no conflicts of interests.

\section{CORRESPONDING AUTHOR}

\section{Luis Guilherme Rosifini Alves Rezende}

Department of Orthopaedics, Trauma, and Anesthesiology

Hospital of Clinics of Ribeirão Preto

Medical School of the University of São Paulo.

Av. Bandeirantes, $3900,11^{\text {th }}$ Floor,

14900-090 Ribeirao Preto, Sao Paulo, Brazil,

e-mail: Igrezende@usp.br 